Cristinel Munteanu, Piteşti*

\title{
On the Real Object of Linguistics
}

\begin{abstract}
"A language, however, does not exist as an object or an organism of nature, and thus it does not have an organic continuity independent of the consciouness of its speakers." (E. Coseriu 1983/1988: 149).
\end{abstract}

\begin{abstract}
In this paper, I aim at proving the fact that those who think they can provide causal explanations in linguistics ignore the specific nature of the object of linguistics, which is a cultural one par excellence. Starting from Aristotle, Coseriu emphasized the importance and role of the final cause for the linguistic activity, in general, and for the linguistic change, in particular. What is more, Aristotle himself (in his Physics, II, 2, 194b) demonstrated the specific way in which - in the case of cultural objects - the formal cause, determined by the final cause (which it gets to coincide with), "is combined" with the material cause. For this very reason, my article will deal primarily with the concept of 'form', as it manifests in culture and as it is discussed by great thinkers such as Cassirer, Coseriu and others.
\end{abstract}

\section{Keywords}

cultural sciences, natural sciences, linguistics, final cause, formal cause, Eugenio Coseriu

\section{B.P. Hasdeu: An Unknown Forerunner of Anti-naturalistic Attitude in Linguistics}

In an introduction to an unfinished history of the Romanian language, entitled Principie de linguistică [Principles of Linguistics], published in 1881, B.P. Hasdeu, an important Romanian linguist - who deserves better appreciation for his contributions - was making a synthesis of the linguistic ideas written up to that moment. He referred, among other things, to A. Schleicher and other advocates of "naturalistic" linguistic conception and declared that such a belief ("that linguistics, to a certain extent, separated from the rest of philology, would be a natural or biological science, as botany, for example") "can only have an anecdotal importance these days. Linguistics is not a natural science, even if it uses a biological method, just as it is not a mathematical science, in spite of the fact that it often resorts to algebrical

* Cristinel Munteanu (born in 1979), PhD (magna cum laude) is currently a lecturer at the University "Constantin Brâncoveanu" of Piteşti (Romania). He published Sinonimia frazeologică în limba română din perspectiva lingvisticii integrale (2007), Lingvistica integrală coşeriană. Teorie, aplicaţii şi interviuri (2012), Frazeologie românească. Formare şi funcţionare (2013), Fundamente ale comunicării (2007, in collaboration), Tehnici de redactare in comunicare (2008, in collaboration), Discursul repetat intre alteritate şi creativitate (2008, as editor) and Tobias Peucer, De relationibus novellis/Despre relatările jurnalistice [Leipzig, 1690 - the first doctoral thesis in the world regarding journalism] (2008, as editor); he has also written more than one hundred articles and papers published in scientific journals and specialized volumes. The philosophy of language, the theory of language, semantics, phraseology, text linguistics, communication, journalistic discourse are only some of the topics among his main fields of interest.

1 In the original version: ,...cum că linguistica în parte, separată de restul filologiei, ar fi o ştiinţă naturală sau biologică, ca botanica, bunăoară" (Hasdeu 1881/1984: 23). All over this paper, the translation into English of the Romanian quotations is mine. 
formulae, with plus, with equation, with proportion, etc., what is more, it is not even scared of the sign $\sqrt{ } . " 2$

1.1. Indeed, Hasdeu had already remarked that "the comparative method is specific to natural sciences, but that does not mean that a science, which uses it, would be a natural science $e o$ ipso. All sciences tend, more or less, to appropriate this method to themselves, even if not all sciences manage to do it to the same extent. It is the object, by all means a well determined object, not the method that constitutes the nature of a science [my emphasis]". ${ }^{3}$ And still, the conception mentioned by Hasdeu was far from having "only an anecdotal importance" at that time. As known, A. Darmesteter, in 1887, would start his book La vie des mots with the famous sentence: „S'il est une vérité banale aujourd'hui, c'est que les langues sont des organismes vivants dont la vie, pour être d'ordre purement intellectuel, n'en est pas moins réelle et peut se comparer à celle des organismes du règne végétal ou du règne animal." (Darmesteter 1887/1946: 3). This "naturalistic" way of looking at languages was disliked by Michel Bréal, who laid blame on Darmesteter's conception - definitely, in terms of respect, for he was his friend - even after the latter's death (see Bréal 1887/1913: 3, 280). ${ }^{4}$

I do not aim at outlining here a history of the influence of natural sciences or mainly of biology on linguistics. It has already been done by other researchers (including me; see Munteanu 2011: 230-239). I have only attempted to draw attention to Hasdeu's correct ideas, namely: linguistics is neither a natural science nor a mathematical science, since the object it deals with is a special one (neither natural, nor formal, but "social") into account, not the methods used, that confer specificity to any science.

1.2. It is doubtless that the most dangerous thing for linguistic science is that of considering language as something else than it really is (as A. Darmesteter, for example, used to do). According to Hasdeu, the peril consisted in the wrong framing of linguistics among the other sciences because of the methods it uses. To Eugenio Coseriu, the danger consists in the idea that language is considered either a formal or a natural object. In this sense, characterizing Bloomfield's descriptivist orientation, Coseriu would say that: „Chi consideri il linguaggio come pura sostanza, cioè guardando solo alla sua materialità e indagando solo quest'ultima, fa del linguaggio un oggetto naturale" (Coseriu 2010: 39). As to Hjelmslev's glossematic orientation, Coseriu would affirm that: „Chi consideri invece il linguaggio come «pura

2 In the orginal version: „,...nu mai poate avea astăzi decât numai doară o însemnătate anecdotică. Linguistica nu este o ştiinţă naturală, măcar că întrebuinţează o metodă biologică, după cum ea nu este o ştiinţă matematică, deşi recurge adesea la formule algebrice, cu plus, cu ecuaţiunea, cu proporţiunea etc., ba nu se sperie nici chiar de semnul $\sqrt{ } . "$ (ibid.: 23-24).

3 In the original version: ,...metoda comparativă este proprie ştiinţelor naturale, de unde însă nu urmează că o ştiinţă, care se servă de ea, ar fi eo ipso o ştiinţă naturală. Toate ştiinţele tind, mai mult sau mai puţin, a-şi apropria această metodă, deşi nu toate reuşesc în aceeaşi măsură. Obiectul, negreşit un obiect bine determinat, iar nu metoda, constituie natura unei ştiinţe." (ibid.: 22-23).

$4 \quad$ It might have been Hasdeu's sound linguistic conception that made Michel Bréal (and Abel Bergaigne) propose him as a member of Société de Linguistique de Paris (the Romanian linguist was elected unanimously on the $4^{\text {th }}$ of February 1882; cf. Poghirc 1968: 68). On the other hand, one must mention that, due to the fact that such ideas were quite rare at the time, E. Coseriu would appreciate M. Bréal "por su perspicaz y robusta concepción del lenguaje" (Coseriu 1958: 23; see also Coseriu 2000: 21-43).

5 Hasdeu is determined in saying, from the very beginning, that: „Nemic [nu este] mai social ca limba, nodul cel mai puternic, dacă nu chiar temelia societăţii" ["Nothing (is) more social than language, the tightest knot, perhaps the basis of society”] (Hasdeu 1881/1984: 8). 
forma», che si manifesta più o meno casualmente in una determinata sostanza, lo tratta come un oggetto formale." (ibid.). Regarding the two theories, the Romanian scholar would state that they are not false, but inadequate, due to incomplete treatment of the object under study.

\section{The Importance of Philosophy to Linguistics}

With distinguished firmness, consistency and coherence, Eugenio Coseriu always advocated the idea that it is necessary for linguistics to correspond to its object. Language is a cultural object. Hence, linguistics is (and has to remain) a science of culture. It is said, with good reason, that one cannot do science regarding an object, unless one knows, beforehand, what that object really is. In what follows, I aim at presenting the specificity of cultural objects, insisting on the particular role that formal cause plays here. I find it hard to believe that somebody who reads (even today!) chapters or studies from Coseriu's work, such as Explicaciones causales y explicaciones finalistas (see Coseriu 1958: 101-134), El antipositivismo (in Coseriu 1981: 52-73), Linguistic change does not exist (Coseriu 1983/1988), and many others, may have doubts on the truth of the ideas supported by the great Romanian scholar. And still... Not all people think in the same manner, and understanding is sometimes corrupted by the different ways in which we assimilated or perceived some important concepts, such as 'knowledge', for instance. Characterizing language as a cultural object, E. Coseriu would state that

the formal cause, if realized, coincides here with finality, and finality is the produced object itself in its cultural and functional value: thus the finality of the activity that produces the Iliad is the Iliad itself as a work of art, and the finality of the romance future tense is nothing else but this future tense itself in its function as a particular tense in a particular verb system. (Coseriu 1983/1988: 148).

This sentence (and other similar ones), is of vital importance, yet, unfortunately, it has not always been understood as it should. It may be caused by the fact that some readers ignore the philosophical background of Coseriu's theory.

2.1. Even from the beginning of The History of the Philosophy of Language (Geschichte der Sprachphilosophie [1969]), Coseriu presents the ideas of some "scholars", according to whom sciences need to get separated from philosophy, in order to emancipate themselves and thus become autonomous. Such a thing - as Coseriu warns - is not possible "dato che i principi della scienza sono contenuti nella filosofia nella misura in cui la filosofia è la base di ogni scienza" (Coseriu 2010: 35). It is known that the principles of Coseriu's integral linguistics are, first and foremost, of Aristotelian origin. Starting with the moment of the publication of the study Forma y sustancia en los sonidos del lenguaje [1954], Coseriu demonstrated excellent knowledge of Aristotle's philosophy.

2.2. Should - on the basis of the principle of tradition - returning to forerunners be a deficiency of Coseriu's conception? Not at all! Thus, Coseriu would remember (and remind us) with pleasure the words of Antonino Pagliaro, his Italian master: "Poiché è sempre utile richiamare quello che pensavano gli antichi su questioni che allora si presentavano in una luce più chiara e non annebbiata dai residui di troppe esperienze speculative." (apud Coseriu 1999: 
9). That is why, preparing the above mentioned discussion, I will resort, apart from Aristotle, to a series of scholars that Coseriu highly appreciated, such as Ernst Cassirer, R. G. Collingwood and John Dewey. All of them - even if they come from different geographical areas - belong to the same large family of thinkers. I would like to state that, whenever possible, I preferred to present, by means of significant quotations, the ideas of these philosophers, reproduced word for word. Such a procedure may at times create the impression of a collage of fragments where I am supposed to simply introduce some linking phrases. However, I think that it is better sometimes to sacrifice a so called "originality" that would mean simply paraphrasing the thoughts of these thinkers rather than deprive readers of the benefit they would get from direct contact with authentic texts. What is more, by the respective quotations (which can also serve as "food for thought"), I would like to draw attention on some aspects which are usually too easily forgotten or ignored.

\section{Culture as Part (and Extension) of Nature (Different Points of View)}

The fact that in contemporary linguistics there is (and it is becoming more and more popular) the tendency to give (only) causal explanations to linguistic phenomena should not be too surprising (but even if it does not astonish us, that does not mean we have to accept such a conception). In the history of philosophy and science one can frequently notice some great thinkers' preference to simplify things and to explain the world and its becoming, starting (if possible) from only one principle or process, one that is applicable to the entire reality.

3.1. For a long period of time, man was taken as a measure of all things. "Humanity" thus extended into nature, even if it only meant naïve explanation of the latter by means of mythology (i.e. natural objects were seen as cultural objects), or more serious attempts to explain the birth and becoming of nature on a philosophical basis, attempts which are justified from a rational point of view. For instance, Aristotle was said to have proceeded "anthropomorphically”: „He had set out from the purposeful action of man and had read this into the whole of nature.” (Cassirer 1942/2000: 91). ${ }^{6}$ What is more, later „Hegel's aspiration and philosophical ambition was to reconcile «nature» and «idea». But instead of this reconciliation he arrives at the subjugation of nature to the absolute idea" (ibid.: 35).

3.2. In time, a totally different conception is being imposed in science (and, subsequently, in philosophy). An "anthropomorphical" view of nature is no longer sustained, but, on the contrary, even "human nature" starts being explained on natural, biological, causal grounds. Man gets to be banished from his own world. The fact that Charles Darwin proved that man is

6 However, such interpretation is criticized by R. G. Collingwood, a very subtle philosopher: „All process involves a distinction between the potential and the actual, and the potential is the seat of a nisus in virtue of which it is forcing its way towards actuality. This conception of nisus as a factor running through the entire natural world, with its teleological implications about ends towards which natural processes are directed, was at one time rejected by modern science as a piece of anthropomorphism. But it is by no mean an anthropomorphic idea, unless we falsely identify nisus with conscious volition. No doubt it would be anthropomorphic in the worst sense to credit the seed with a knowledge of what it is trying to do, an imagination of itself as a full-grown plant; but because the seed does not know that is trying to become a plant we are not entitled to say that it is not unconsciously trying to do so." (Collingwood 1945/1960: 83; see also ibid.: 84-85). 
nothing but a developed ape highly stimulated such approaches. Consequently, man himself is subject, in all respects, to the laws of nature, while his behavior, even if more complex, does not differ essentially from that of other organisms.

\subsubsection{In this sense, J. von Uexküll demonstrated that}

every organism presents a self-enclosed world in which everything «weaves itself into the whole». The organism is no aggregate of parts but a system of functions that are mutually dependent on each other. In the «blueprint» of every animal we are able to read off immediately the nature of this interconnection. (ibid.: 23).

Which would thus be the consequences of this discovery?

The study of these blueprints shows us that in this respect there is no difference between the lower living creatures and the most higly developed. For each ever-so-elementary organism we can establish a determinate «receptor system» and a determinate «effector system»; in each we can clarify how its various «functional spheres» mesh with each other. (ibid.: 23-24).

3.2.2. Even John Dewey, ${ }^{7}$ highly attentive to the difference between nature and culture, ${ }^{8}$ while defining the concept of 'inquiry', tries to preserve the same unity of the whole biological world: "Inquiry is the controlled or directed transformation of an indeterminate situation into one that is so determinate in its constituent distinctions and relations as to convert the elements of the original situation into a unified whole." (Dewey 1938: 104-105). In short, inquiry ,,is the resolution of uncertainty as it arises in concrete situations” (Burke 1994: 140). Thomas Burke - who probably knows best Dewey's logic - confirms the previously mentioned idea:

Dewey's picture of inquiry describes general architectural and dynamic features of virtually any constituent subsystem of living animals, characterizing the simplest cellular life functions as well as the most complex motor activities. Indeed, this definition of inquiry is aimed at characterizing not only the microstructure of physiological behavior but also wholesale features of human sociocultural interactions. By this account, agents should be motivated to solve problems independently of whether or not they have minds. (ibid.: 141).

3.2.3. In this context, some other more complex modern theories are worth mentioning, since they strive to explain the becoming of the whole world in a systematic, coherent and unitary way, which reminds us of Plato and Aristotle. In the last chapter of his extraordinary book, The Idea of Nature, R. G. Collingwood deals with modern cosmology, by presenting the conceptions of two great philosophers, Alexander and Whitehead, his contemporaries. The two conceptions are similar, since both of them try to explain the world as it exists in its ceaseless changes, "as a single cosmic process in which there emerge, as it goes on, higher orders of being" (Collingwood 1945/1960: 150). Alexander's view of evolution (which is somehow related to Hegel's and Lloyd Morgan's) is summarized by Collingwood as follows:

7 John Dewey was one of the first thinkers to assess the impact of Ch. Darwin's theory in philosophy.

8 Mention must be made that E. Coseriu highly appreciated J. Dewey, considering him the greatest American thinker. 
He accepts the general scheme [...] of life as emerging from matter and mind from life, and he holds that in both these emergences - and similarly in all others - the essence of the process is that, first, there exist things with a determinate structure and character of their own, and then, that these things arrange themselves into a new pattern which as a whole possesses a new type of structure and a new order of qualities. The fundamental conception here implied is the conception that quality depends on pattern. (ibid.: 159).

We should not get into much detail at this point. Collingwood observes that Whitehead's theory is superior to Alexander's, since "Alexander's cosmic process [...] rests on a single foundation, space-time; Whitehead's on a double foundation, space-time and the eternal objects" (ibid.: 169). It is this difference that allows Whitehead "to solve certain fundamental problems which for Alexander remain necessarily insoluble" (ibid.). In his cosmology (developed in the book Process and Reality [1929]), Whitehead starts by being Platonic, but, in time, he becomes an Aristotelian (even if he did not read Aristotle's Metaphysics!). Collingwood manifests deep admiration for Whitehead: "No one has more vividly realized and described the resemblances, the fundamental continuity, running all through the world of nature, from its most rudimentary forms in the electron and proton and the rest of them to its highest development known to us in the mental life of man" (ibid.: 174).

In spite of this declared admiration, Collingwood, who was endowed with a highly developed critical sense, is not convinced by the way in which Whitehead defines both the concepts «life» and «mind», remarking "his [= Whitehead's] refusal to regard mind as something utterly disparate from nature, his insistence that mind as we know it in man is something that has come to be what it is by developing functions belonging to life in general and even in the last resort to the inorganic world" (ibid.). ${ }^{9}$

It is usually believed that it is the mind that differentiates us from the rest of beings. Whitehead is trying to prove that the difference under study would not be that big:

The characteristic mark of mind is that it knows, apprehends reality. Now, says Whitehead, this too, like the characteristics of life, is nothing really unprecedented. Everything enjoys what he calls 'prehensions', that is to say, somehow absorbs what is outside itself into its own being. An iron filing prehends the magnetic field in which it lies, that is, it converts that field into a mode of its own behaviour, responds to it; a plant prehends the sunlight, and so on. The peculiarity of what we ordinarily call 'minds' is that they prehend an order of things which no lower type of organism can prehend, namely propositions. (ibid.: 173-174).

9 At this point, I cannot refrain myself from giving an extraordinary quotation in which Coseriu refers to 'mind': “Ahora, el negar la mente, por no tratarse de una cosa perteneciente al mundo (o reducirla a actos físicos), es una decisión arbitraria que tiene el mismo carácter «metafísico» y convencional de la decisión contraria: la de negar las cosas del mundo porque no partenecen a la mente (o reducirlas a actos mentales). En realidad, no es de ningún modo necesario entender el espíritu o la mente como sustancias metafísicas para reconocer el carácter «espiritual» de ciertas actividades o la interioridad, la no-mundanidad de la conciencia (que sólo significa reconocer la distinción entre sujeto y objeto, condición ineludible de nuestro conocimiento). El espíritu puede concebirse simplemente como concepto, y no objeto: como un concepto deducido de ciertas actividades, el principio único a cual las reducimos para entenderlas como unidad (o como el conjunto de estas mismas actividades). Del mismo modo, la mente puede entenderse como puro concepto, como nombre de la interioridad de la conciencia (del sujeto como no-integrante del objeto), aunque se pueda demonstrar que también tal interioridad es de carácter físico. No se puede negar tal interioridad con el pretexto de que acerca de su existencia sólo tenemos las pruebas ofrecidas por la experiencia corriente (por la «popular view»), porque acerca de las cosas del mundo no tenemos otras pruebas que las de esta misma experiencia: «se dice» que existen las cosas del mismo modo que «se dice» que existe la mente" (Coseriu 1954/1967: 136). 
Let us keep in mind, for a while, the importance of these ,propositions” (meaning here 'judgments', 'statements' or, simply, 'sentences') as a specific feature of mind and of man, accordingly.

3.3. All these attempts to homogenize the continuum (inorganic) matter - life - mind are opposed a series of observations made by the advocates of culture.

3.3.1. With reference to the things demonstrated by J. von Uexküll, Ernst Cassirer adds that "the «receptor world» and the «effector world» of animals acquire something new in the human sphere: they are joined by an «image world»; and it is this image world that gains more and more power over man as it develops." (Cassirer 1942/2000: 26). In this way, the German philosopher points out a distinctive feature of man as contrasted with the rest of the biological world:

Uexküll once said that the blueprint of each living being, and the relation that it determines between its «receptor world» and its «effector world», encloses this being as firmly as the walls of a prison. Man escapes from this prison not by tearing down its walls but rather by becoming conscious of them. Here the Hegelian statement holds good, that he who knows about a limit is already beyond it. This becoming conscious is the beginning and the end, the alpha and omega, of the freedom that is granted to man; to know and to aknowledge necessity is the genuine process of liberation that «spirit», in opposition to «nature», has to accomplish. (ibid.: 25).

3.3.2. As to what J. Dewey is concerned, mention must be made that he used the concept of 'inquiry' consistently, without altering concepts such as 'life' and 'mind'. On the contrary, he focused on what is common to the two worlds. In fact, since defined from the very beginning, rigorously, the respective concept should not cause misunderstandings (however, Bertrand Russell showed great narrow-mindedness as to what Dewey' logic is concerned; see Burke 1994). For instance, the way in which J. Deeley, a well-known specialist in semiotics, defines the concept of 'semiosis' (i.e. the actions of signs) allows for extension of the subject matter of semiotic inquiry, not only to the organic realm, but to the whole physical environment (see Deely 1990: 22-32).

3.3.3. Even if Ernst Cassirer makes no reference to Whitehead and to the way (doubtful, according to Collingwood, as well) in which he saw the birth of mind and, thus, of propositions, he seems to respond to Whitehead in the following quotation: "If one wanted to let language to emerge from nature through some causal intermediaries, there was no other possibility than to tie it immediately to certain phenomena of nature. It had to be shown to be interpreted as a spiritual process." (Cassirer 1942/2000: 98). According to Cassirer, all such attempts were doomed to failure. All theories that have tried to explain the origin of language by means of "causal inquiry" (based on the category of cause and effect) were frustrated by the fundamental phenomenon of all speech, id est the phenomenon of the sentence:

As long as there was no success in explaining the sentence as a mere aggregate of words, as soon as it was seen in its actual «construction», it became apparent that there is no formation in nature that corresponds to this construction. Nor can the return to «primitive» stages of language show us the way here; for each linguistic phenomenon, however primitive, already contains the whole of language 
within itself, because it encloses the function of «signification» and «intention» within itself. (ibid.: 99).

3.3.3.1. The following experiment demonstrates the fact that the philosophers of culture have been right. In a long chapter of his book, The Play of Musement (see Sebeok 1981/2002: 106187), ${ }^{10}$ Thomas A. Sebeok, the founder of zoosemiotics, makes an evaluation of the attempts that some specialists made in order to teach animals to speak. The richest information concerns the acquisition of language at apes. After having worked many years with these animals, researchers had to admit the fact that apes - even if they can learn to use, out of practical reasons, a few "symbols" - cannot acquire even the most basic grammar "notions"; in other words, their "language" does not have anything of what is called "syntax" (ibid.: 183-184). Thus, it has been proved experimentally that apes do not actually have the ability to make sentences.

Undeniably, if scientists had taken the great philosophers seriously, they would have realized from the very beginning that such a thing is impossible. ${ }^{11}$ Aristotle emphasizes this idea in his Politics (I, 2, 1253a), while, according to Hegel, man is not an animal at all, since, in comparison with the latter, he is endowed with two fundamental dimensions: work and language (see Coşeriu 2004a: 54-56).

Unmistakably, animals do communicate in a way or another, but in their case (for instance, in the case of bees, whose communication was studied for many decades by Karl von Frisch; cf. Benveniste 1966: 56-62), there is no authentic dialogue, but only certain reactions to certain stimuli in concrete situations. Human language - as Coseriu states - "fully frees us from the concrete, material context and from the contact with things. Our things are always universal in language, and these things can be thought in our consciousness". ${ }^{12}$

3.3.3.2. In fact, the specific difference of human language was also signaled long ago by Hermann Paul, a great linguist, who, wondering about the extent at which the language ,of the beasts" is similar to that of humans, was stating that "it will hardly be disputed that their calls, whether of enticement or warning, are traditional and not spontaneous" (Paul 1891: 189). However, there is no doubt that

the strict characteristic which differentiates the language of men from that of animals, existing language from a previous linguistic stage, consists in something very different. This decisive advance consists in the collocation of several words into one sentence. Only thus does man receive the power to free himself from simple intuition, and to pronounce judgment on what is not before him. (ibid.).

10 I will refer to the Romanian version of this book, which presents a further chapter, added to the original from 1981.

11 Similarly, Eugenio Coseriu affirms that great sums of money were spent on automatic translation programs, even if it should have been told from the beginning that it can never be done satisfactorily. In fact, when Coseriu was called at Grenoble or at other research institutes, he was asked for his opinion on these problems and he answered: "It is useless, we will get to translate more and more, but never a complete text, for no text contains all its contexts" (Coşeriu 2004b: 102-103; my translation). And, of course, the same thing could have been said about the famous Turing test.

12 In the original version: ,[limbajul] ne eliberează cu totul de contextul concret, material şi de contactul cu lucrurile. Lucrurile nostre, în limbaj, sunt întotdeauna universale, lucruri care pot fi gândite în conştiinţă." (Coşeriu 2004a: 57) 


\section{On the Essence of Cultural Objects and, accordingly, of Language}

Starting from the configuration of the relationship between form (morphé) and substance (hýle), according to Aristotle (in Physics, II, 2, 194a-b) and G. Vico (in Scienza nuova secunda), Eugenio Coseriu states that objects can be classified in three classes:

a) natural objects, seen as substances that have a certain form. In this case, form (F) is determined by substance $(\mathrm{S})$; in other words, a certain substance (either organic or inorganic) is crystallized in a certain way $(\mathrm{S} \rightarrow \mathrm{F})$;

b) mathematical or formal objects, which are pure forms (only F), not connected to substances (since mathematical objects do not exist beyond our consciousness);

c) cultural objects, in whose existence it is the form that is the most important, but only in connection with substance, that means form chooses the most appropriate substance $(\mathrm{F} \rightarrow \mathrm{S})$. In order to be more exact, we have to mention that the classification belongs to the Stagirite, but it is Coseriu that justified it in depth. He was mainly interested in the specific features of cultural objects, including language (see Coşeriu 1994: 8, 23).

4.1. Cultural objects are, in fact, forms of consciousness which, in order to be exteriorized, to be made known to the others or be made intersubjective, one has to transpose them in a substance felt by senses. People are thus "closed consciousness" who can communicate but through substances ${ }^{13}$ that are not irrelevant or hazardous. For instance, the ancient Greeks represented, in sculpture, the women by using the marble of Paros, since it allows light to penetrate up to $1 \mathrm{~cm}$ and thus it better corresponds to their idea of feminity; on the contrary, men were made of bronze, since it is an opaque substance, which emphasizes muscles and contours, etc. Similarly, musical pieces were composed especially for a certain instrument (cf. Coşeriu 1994: 23). ${ }^{14}$

4.2. The same remarks hold good in the case of language, where the form of consciousness (namely, the meaning as signifié) is conclusive:

hay que advertir que el lenguaje es, en efecto, expresión con significado, pero que en el lenguaje el significado, y no la expresión, es lo determinante y que, por tanto, la expresión existe por el significado, no a la inversa; o, dicho de otro modo, que el significado es finalidad o función del lenguaje, mientras que la expresión vale sólo como instrumento de esta función. De aquí que, en principio, el instrumento pueda ser una cualquiera. Por consiguiente, sería mejor decir que el lenguaje es significado expresado, significado con expresión, y no a la inversa. (Coseriu 1977/1991: 38).

4.3. The previously mentioned ideas are also true for concrete linguistic acts. Proving what the essence of artistic literature (as discourse) consists of, compared to other types of discourse (such as the journalistic one, for example), Coseriu points out that discourses, as voluntary human acts, cannot be defined by their structure (which is their material cause), but only by their final cause, decisive in human activities. As already seen, in culture, structure

13 Here (and elsewhere in this paper) the term substance, as used by Coseriu, has to be understood as 'matter' and not in a philosophical sense, as 'being' (as in the O. Gr. ousia.).

14 The relation between form and substance was properly understood and discussed by John Dewey in some of his books (see, for instance, Dewey 1934/2005: 110-138 and Dewey 1958: passim). 
has to be always in accordance with its finality and not the other way round (see Coseriu 1990/2006: 91).

4.4. However, if everything that characterizes culture in general is true for language as well, then - either in the case of language or discourses - substance is not irrelevant here, too. Even if in language, in principle, the instrument can be anything (according to Hjelmslev), Coseriu proved (starting with 1954, in Forma y sustancia en los sonidos del lenguaje) that sounds are not chosen at random. The same is true for discourses, even if we are situated at a more complex level. For example, we could consider styles as substances (or expressions) previously formed which speakers have at their disposal, not at all by chance, according to their communication necessities. This is how Coseriu's ideas, mentioned in a footnote from his famous book, Sincronía, diacronía e historia [1958], have to be understood:

La Crítica de la razón pura y la Fenomenología del espiritu son también obras literariamente logradas porque su forma de expresión corresponde, aun en sentido «subjetivo», a su finalidad expresiva, y no lo serían si presentaran, por ej., el estilo de una novela policial. En cambio, una historia de la filosofía como la de B. Russell molesta - entre otras cosas más graves - también por su estilo conversador y periodístico. (Coseriu 1958: 96).

\section{Eugenio Coseriu's Classification of Sciences}

In what follows, I will present what I find to be the best classification of sciences. It takes into account, first and foremost, the objects each type of science deals with (see Coseriu 2010: 3540). Benefitting from the reflections of some philosophers (such as Aristotle, G. Vico and J. Dewey), E. Coseriu classifies sciences starting from the questions they raise regarding the essence (or quid) of things and beings.

5.1. Thus, it is $(\alpha)$ history that gives the (justified and complex) answers to the questions on the essence of individual, since history itself is the science of the individual.

The $(\beta)$ sciences of the general offer the answers to the question regarding the essence of a class (namely the essence of the things that correspond to a certain concept). They are of three types, according to the object they study (see above, 4 .):

(1) mathematical sciences, "dealing with purely formal objects and relations" (Coşeriu 1994: 8);

(2) natural sciences, about "objects external to man and with man (seen as external object), with objects that are first presented as determined substance, as matter crystallized in a certain way, while it is the substance that gets shaped" (ibid.);

(3) cultural or humanistic sciences, referring to

objects that are freely created by man and which are primarily forms in our consciousness (have their own internal existence), which get certain substance with a view to becoming concrete in the world and thus be intersubjective; language, art, religion and other products of cultural activity, of spiritual activity and of the creative activity itself are eloquent cases in point (ibid.).

Going deeper into the subject, one must mention that there is also another science, situated at another level, "a science that asks questions regarding the essence of essence, the quid of 
quid" (ibid.). That is $(\gamma)$ philosophy or the science of universal, which leads us to the first principles of every mode of being. For instance, the philosophy of language tries to distinguish language from other types of objects which have certain features in common, such as: "art presented as expressivity, similar to language; practical activity, which can use and uses language as a tool; or rational thinking, which is not possible in the absence of language" (ibid.: 9).

5.2. A crucial error (which can still be found these days) that positivists had made was that of identifying the objects of culture with those of nature, by applying specific methods of natural sciences to cultural sciences. However, in a given situation, approaches can no longer be scientific, since the conditio sine qua non of scientific activity is "objectivity" itself, that is making it adequate to the corresponding object. Having also referred to I. Kant's distinction between "necessity" and "freedom" (also previously intuited by G. Vico), Eugenio Coseriu clearly states that:

Los objetos naturales pertenecen al mundo de la «necesidad», gobernado por «causas» que producen determinados «efectos» y donde, por tanto, la comprobación de lo que ocurre constantemente, en determinadas condiciones, representa una «ley natural» o ley de la necesidad empírica. Los objetos culturales, en cambio, pertenecen al mundo propiamente humano de la libertad - de las actividades y creaciones libres del hombre -, donde los «hechos» creados no están determinados por causas, sino que se producen con vistas a una finalidad y, como realizaciones logradas - si no se trata de «instrumentos», que tienen también una finalidad exterior -, coinciden con su finalidad; así, la finalidad de la Ilíada es la Ilíada misma. (Coseriu 1981: 69).

\section{Some Difficulties Raised by the Science of Life or Biology}

As already noticed, Coseriu sees the whole natural world in a unitary way, even if the matter is either inorganic or organic, that is why he does not add further distinctions within natural sciences. In fact, if one takes into account only the relation between form and substance, in the case of natural objects (be it a mountain, a tree or an animal) substance/matter crystallizes in a similar way.

Nevertheless, one must observe that, in the case of natural sciences, biology has its special place, since it studies 'life', and that triggers methodological characteristics, different from those that define physics or chemistry. For instance, according to some scholars, the specific character of life would give priority to teleological explanations, to the detriment of the causal ones. It has long been believed that only the sciences which pursue explanations by means of universal, highly predictive laws, are the "real" sciences, whereas biological and social subjects are not entitled (for this very reason) to be called "sciences". ${ }^{15}$ Some time ago (in 1865), Claude Bernard, the French physiologist, was convinced that there is no difference between the principles of biological sciences and those of physics and chemistry (cf. Flonta 2010: 276). However, things are more complicated than they seem to be.

15 Actually, the fact that a science (just as the one dedicated to the evolution of life) resorts to explanations by means of historical narrations does not make it less scientific than a science which gives explanations triggered from experimental research. For the difference between history and natural sciences, see Collingwood 1946/1956: 214. 
6.1. Mircea Flonta, highly interested in the philosophy of biology, states that "the thesis of the methodological unity of natural sciences will be well defended as long as sciences such as biophysics, biochemistry, physiology and molecular biology are considered as representative of biological research in general" (ibid.: 282). On the other hand, "if we consider other domains of biological research which deal with the study of the evolution of life on Earth or the behavior of superior animals" (ibid.), the methodological coherence previously mentioned cannot be brought forward anymore. ${ }^{16}$

6.2. In fact, starting from these considerations, Mircea Flonta goes deeper into the subject, stating that there is no clear separation between humanities (cultural sciences) and natural sciences:

As a matter of fact, the explanations from the biology of evolution are not based on laws, but on concepts such as: overpopulation, fight for survival, natural selection, adaptation, reproductive success, etc. [Ernst] Mayr mentioned that, due to the epistemic profile of its explanations, the biology of evolution is closer to social history than to theoretical physics. It proves that the persistent supposition that one could trace a clear separation line between natural sciences and humanities is quite illusory [my emphasis] (ibid.: 300).

Still, I find this assertion exaggerated. The criteria that E. Coseriu established (see supra, 5.1.) are relevant enough in order to draw a clear distinction between the two types of sciences.

6.3. Ernst Cassirer would remark that, by identifying some concepts such as 'wholeness' and 'structure', the differences between the two categories of sciences were not removed. Nevertheless, this modern "discovery" led to the conclusion that the forms and structures the cultural sciences deal with have their own particular features:

The recognition of the concept of wholeness and of the concept of structure has by no means effaced or eliminated the difference between the sciences of nature and the sciences of culture. But it has eliminated a separating barrier that until now has stood between them. The science of culture can immerse itself in the study of its own forms, its own structures and formations [Gestalten] with greater freedom and ease than before, as the other fields of knowledge have become more attentive to their own particular problems of form. (Cassirer 1942/2000: 96).

\section{By Way of Conclusion}

The fact that the forms of culture are internal forms of consciousness is undeniable. Language is lógos semantikós (according to Aristotle), while the meaning (signifié) is found in the speakers' consciousness, becoming objective by means of intersubjectivity. All these things have been said by great thinkers (Coseriu included). Modern linguistics should take philosophy seriously, so as not to stray away uselessly (trying, as zoosemiotics did, for instance, to prove that apes can "talk", although it has long been proved rationally that apes

16 In 1968, the British zoologist Carl F.A. Pantin forwarded the distinction restricted (physical) sciences vs. unrestricted (biological) sciences, affirming that sciences such as biology and geology differ from physical sciences precisely because of the richness and complexity of the phenomena they investigate. Almost two decades later, Richard Dawkins will see things in a similar way, pointing out that biology, unlike physics, studies more complicated objects, which give the impression of having been projected (Flonta 2010: 310). 
cannot talk as humans do). Thus, as long as there is "man and his language", the explanations that linguistics has to give are the final, not the causal ones. The latter, when provided, only refer to accidental cases/facts.

\section{Bibliography}

Benveniste, Émile (1966): Problèmes de linguistique générale [vol. I]. Paris: Éditions Gallimard.

Bréal, Michel (1913 [1897]): Essai de sémantique. Science des significations, Sixième édition. Paris: Librairie Hachette et $C^{\text {ie }}$.

Burke, Tom (1994): Dewey's New Logic. A Reply to Russell. Chicago and London: The University of Chicago Press.

Cassirer, Ernst (2000 [1942]): The Logic of the Cultural Sciences. Five Studies, Translated and with a Introduction by S.G. Lofts, Foreword by Donald Phillip Verene. New Haven and London: Yale University Press.

Collingwood, R. G. (1960 [1945]: The Idea of Nature. London, Oxford, New York: Oxford University Press.

- (1956 [1946]): The Idea of History. London, Oxford, New York: Oxford University Press.

Coseriu, Eugenio (1967 [1954]): "Forma y sustancia en los sonidos del lenguaje" [1954], en Coseriu, Eugenio (1967): Teoría del lenguaje y lingüistica general. Cinco estudios, Secunda edición. Madrid: Editorial Gredos, 115-234.

- (1958): Sincronía, diacronía e historia. El problema del cambio lingüistico. Montevideo: Universidad de la Republica. Facultad de Humanidades y Ciencias.

- (1991 [1977]): El hombre y su lenguaje. Estudios de teoría y metodología lingüistica, Segunda edición, revisada. Madrid: Editorial Gredos.

- (1981): Lecciones de lingüística general. Madrid: Editorial Gredos.

- (1988 [1983]): "Linguistic Change Does not Exist", in J. Albrecht, J. Lüdtke \& H. Thun (eds.): Energeia und Ergon. Sprachliche Variation - Sprachgeschichte - Sprachtypologie. Studia in honorem Eugenio Coseriu, vol. I: Schriften von Eugenio Coseriu (1965-1987). Tübingen: Gunter Narr Verlag, 147-157.

- (2006 [1990]): "Información y literatura", en Eugenio Coseriu/Óscar Loureda Lamas (2006): Lenguaje y discurso. Pamplona: EUNSA, 85-99.

- (1994): Prelegeri şi conferinţe (1992-1993), ca supliment al publicaţiei Anuar de lingvistică şi istorie literară, T. XXXIII, 1992-1993, Seria A, Lingvistică. Iaşi.

- (1999): Un libro classico [as a foreword to] Antonino Pagliaro (1999), La parola e l'immagine [new edition]. Palermo: Novecento, 5-10.

- (2000): "Bréal: su lingüística y su semántica", en Cien años de investigación semántica: de Michel Bréal a la actualidad, en Actas del Congreso Internacional de Semántica (Universidad de La Laguna, 1997). Madrid, 21-43.

- (2004a): Universul din scoică (interviuri). Chişinău: Editura Ştiinţa.

- (2004b): Prelegeri şi seminarii la Universitatea „Lucian Blaga” din Sibiu. Sibiu: Editura Universităţii „Lucian Blaga” din Sibiu.

- (2010): Storia della filosofia del linguaggio, Edizione italiana a cura di Donatella Di Cesare. Roma: Carocci editore. 
Darmesteter, Arsène (1946 [1887]): La vie des mots. Étudiée dans leur significations. Paris: Librairie Delagrave.

Deely, John (1990): Basics of Semiotics. Bloomington \& Indianapolis: Indiana University Press.

Dewey, John (2005 [1934]): Art as Experience. New York: Penguin Group.

- (1938): Logic. The Theory of Inquiry. New York: Henry Holt and Company.

- (1958): Experience and Nature. New York: Dover Publications, Inc.

Flonta, Mircea (2010): Darwin şi după Darwin. Studii de filozofie a biologiei. Bucureşti: Editura Humanitas.

Hasdeu, B. Petriceicu (1984 [1881]): Istoria limbei române, Partea I. Principie de linguistică, în Cuvente din bătrâni, Tomul III, Ediţie îngrijită şi note de G. Mihăilă. Bucureşti: Editura Didactică şi Pedagogică.

Munteanu, Cristinel (2011): "Viaţa cuvintelor şi selecţia lor naturală (sau despre influenţa biologiei asupra lingvisticii)", în Communication interculturelle et littérature, 2 (14). Galaţi: Editura Europlus, 230-239.

Paul, Hermann (1891 [1890]): Principles of the History of Language, Translated from the second edition of the original by H.A. Strong, New and revised edition. London: Longmans, Green, and Co.

Poghirc, Cicerone (1968): B. P. Hasdeu. Lingvist şi filolog. Bucureşti: Editura Ştiinţifică.

Sebeok, Thomas A. (2002 [1981]): Jocul cu fantasme. Semiotică şi antropologie, Traducere şi postfaţă de Mariana Neţ. Bucureşti: Editura All. 